\title{
Immigration and local spending in social services: Evidence from a massive immigration wave
}

\author{
Jordi Jofre-Monseny, Pilar Sorribas-Navarro and Javier Vázquez-Grenno \\ Universitat de Barcelona \& Institut d'Economia de Barcelona (IEB)
}

March 2016

\begin{abstract}
The aim of this paper is to analyze the relationship between immigration and redistributive public spending by using the recent, massive arrival of immigrants in Spain. Specifically, we focus our analysis on the effect of 1998-2006 changes in local immigrant density on contemporaneous changes in municipal spending in social services. To address the potential endogenous location of immigrants, we adopt an instrumental variables approach that uses the distribution of rental housing in 1991 to predict the location of immigrant inflows. The results indicate that (per capita) social spending increased less in those municipalities that recorded the largest increases in immigrant density. We interpret our results as a reduction in natives' demand for redistributive public spending.
\end{abstract}

Keywords: Social services; public sector spending; immigration; redistribution.

JEL Codes: I3; J61; H7

Contact Address:

Departament d'Economia

Avda. Diagonal 690, Torre 6, Planta 2,

08034, Barcelona, Spain

e-mail: jordi.jofre@ub.edu; psorribas@ub.edu; jvazquezgrenno@ub.edu. 


\section{Introduction}

There is a large literature on the effects of immigration on several economic outcomes of host countries including wages, unemployment, consumer and housing prices and innovation ${ }^{1}$. Immigration might also affect public spending (and income redistribution). Specifically, immigration might reduce public spending by two different channels. Firstly, immigration increases ethnic heterogeneity which might reduce the preferences for income redistribution if there is a tendency to favor redistributive policies among beneficiaries belonging to their same ethnic group (Alesina et al. 2001; Alesina and Glaeser 2004). Secondly, (low-income) immigration might increase the cost of redistribution for natives if there is a "fiscal leakage" from the native-born to the immigrants (Razin et al. 2002, Razin 2013).

Although Spain has traditionally been a country of emigration, it has received massive inflows of (mostly low-skilled) immigrants in recent times. Between 1998 and 2006, the proportion of foreign-born within the total population increased from 2.9 to 10.8 percent $^{2}$. As Table 1 shows, immigrants were ethnically heterogeneous as significant inflows originated from different countries in Africa, South-America, Eastern Europe and Asia. We use this unique immigration episode to shed light on the relationship between immigration and income redistribution by estimating the effect of immigration on local spending in social services which roughly accounts for 11 percent of the municipalities' budgets. We focus on social services because it clearly constitutes the most redistributive spending component of local governments. More specifically, we exploit the highly uneven geographical distribution of immigrant inflows within Spain to estimate the effect of

\footnotetext{
1 See Kerr and Kerr (2011), Chiswick and Miller (2014) and Lewis and Peri (2015) for recent reviews on the economics effects of immigration on host countries.

2 During the period 1998-2006, among the developed countries, Spain was the second highest recipient of immigrants in absolute terms (behind the US) and the highest relative to its population level (OECD-International Migration Database).
} 
changes in immigrant density (measured as the share of non EU15 immigrants in the municipality) on changes in public expenditures in social services.

In the period we study, Spain provides us with an appropriate testing ground to empirically assess the effect of immigration on redistributive public spending. First and foremost, we document changes in redistributive spending at a time when Spain received a massive inflow of immigrants that have access to public services regardless of their legal status. Second, municipal governments have a large degree of autonomy as regards their spending decisions. On the one hand, upper-level governments do not set any minimum standards as regards specific spending programs. On the other hand, grants to local governments are not ear-marked, are (mostly) distributed on a per capita basis, and do not increase with immigrant density (or any feature such as income or unemployment that could correlate with immigrant density). As a result, there is substantial variation across municipalities in social services spending. Finally, Spanish municipalities are relatively small, meaning that immigrant density at the municipal level provides a better measure of local ethnic composition than measures used in studies conducted at broader geographical levels (e.g. the US states).

Since shocks in immigrant density might be correlated with shocks in social services spending we resort to an instrumental variables approach. The type of housing available is an important determinant of immigrants' location choices (see e.g. Damm 2009; Harmon 2014; Boeri et al. 2015; Verdugo 2016). We follow Harmon (2014) and use long-lagged housing characteristics to predict immigrants' location choices ${ }^{3}$. Specifically, the instrument that we use exploits the distribution of rental housing in 1991 to predict where the immigrants locate in the period 1998-2006. To assess the validity of the instrument, we report how instrumental variables' estimates are affected by the inclusion of baseline

\footnotetext{
${ }^{3}$ In his study of the effect of immigration on vote outcomes, Harmon (2014) uses long-lagged measures of rental housing availability to predict subsequent immigrant density changes.
} 
municipality characteristics (measured in 1998) and test if predicted immigrant inflows correlate with pre-treatment (1992-1996) changes in social services spending.

Our results support the hypothesis that immigration reduces income redistribution. Specifically, the results of our preferred specification imply that an immigrant density increase of 6.9 percentage points (the 1998-2006 change in the proportion of non EU15 immigrants in Spain) reduces municipal spending in social services by $32.5 €$ per capita, which amounts to 29.2 percent of the variable's mean in 2006. This result survives a number of robustness checks and is not driven by changes in aggregate municipal public spending. Since non-EU immigrants cannot vote in Spanish local elections, we interpret our results as a reduction in natives' demand for redistributive public spending.

Ribar and Wilhelm (1999), Alesina et al. (2001) and Alesina and Glaeser (2004), relate ethnic heterogeneity with the generosity of the Aid to Families with Dependent Children (AFDC) program in US states. They find that an increase in the share of AfricanAmericans decreases the average AFDC monthly payment. In a related paper, Lind (2007) computes indices of income inequality within and between ethnic groups at the US state level, concluding that while income inequality between groups tends to reduce redistribution (measured as the ratio of welfare transfers to state personal income), income inequality within groups tends to increase it. Finally, Alesina et al. (1999), when examining the public expenditure of US cities, metropolitan areas and counties, find that ethnic heterogeneity (proxied by an index of racial fractionalization) tends to reduce the provision of productive public goods and welfare spending. While these US studies shed light on the link between ethnic heterogeneity and income redistribution in settings where all ethnic groups participate in the political process, our study reflects the change in the demand for income redistribution by one ethnic group (the natives) given an inflow of (low-skilled and ethnically heterogeneous) immigrants. 
Razin et al. (2002) and Speciale (2012) estimate the effect of immigration on income redistribution using country-level data. Their results suggest that countries receiving larger immigration inflows reduce redistributive public spending. The paper that is closer to ours is Gerdes (2011) who analyzes the effect of immigration on local public spending (daycare, schools, healthcare, and care for the elderly) in Danish municipalities in the period 19952001. He finds that the share of immigrants does not affect the value of publicly provided goods consumed by native Danes. We complement these studies in two ways. First, we estimate the effect of immigration on redistributive local spending by examining changes in local spending patterns and immigrant density in a period (1998-2006) characterized by huge increases in foreign-born population. Second, we use a novel instrumental variables approach that exploits the availability of rental housing (measured before the immigration wave) to predict where immigrant density actually increased.

Our paper is also related to the literature that estimates the effect of ethnic heterogeneity on self-reported measures of preferences for redistribution. Alesina et al. (2001) and Luttmer (2001) examine self-reported measures of support for redistribution drawn from the US General Social Survey. While Alesina et al. (2001) find no evidence that whites living in more heterogeneous states are less likely to express support for welfare spending, Luttmer (2001) shows that people are more likely to express support for such spending if they live in a neighborhood where their own ethnic group is highly represented among welfare recipients. Two European studies are Senik et al. (2009) and Dahlberg et al. (2012). Senik et al. (2009), drawing on data from the European Social Survey (2002/2003), find weak evidence of a negative relationship between the perceived presence of immigrants and native support for redistribution. Dahlberg et al. (2012) estimate the effect of immigrant density on individual preferences for redistribution in Swedish municipalities. They exploit an exogenous variation in municipal immigrant density induced by a refugee 
placement program, finding that ethnic heterogeneity results in less support for redistribution.

The remainder of the paper is organized as follows. In Section 2, we first introduce a very stylized theoretical framework to contextualize the empirical findings of the paper. In Section 3 we introduce the data and the sample of municipalities used in the analysis. Then, we explain some features of the Spanish immigration boom. We conclude this section by describing the institutional background of local governments in Spain. In Section 4, we introduce the econometric specification, discuss the identification challenges faced, and present and discuss the results. Finally, Section 5 concludes.

\section{Theoretical background}

To better understand the channels through which immigration might affect the demand for local social services, we use the median voter approach followed by Ribar and Wilhelm (1999). An individual's utility, $U(c, a)$, depends on private good consumption, $c$, and on the protection level received by each social services user, $a$. Social services are financed by local residents on a per capita basis. Thus, an individual's budget constraint is $y=c+(R \cdot a) / N$, where $y$ is (exogenous) income, $R$ is the population of social services users and $N$ is total population. Note that the budget constraint can be written as $y=c+p \cdot a$, where the fraction of population using social services, $p \equiv R / N$, is the tax-price. We depart from Ribar and Wilhelm by assuming the (quasi-linear) utility function $U(c, a)=c+a^{\beta}$ with 0 $<\beta<1$, where the parameter $\beta$ reflects the intensity preferences for redistribution. The first order condition is given by:

$$
a=p^{\frac{1}{\beta-1}} \cdot \beta^{\frac{1}{1-\beta}}
$$


The implemented policy is solely determined by the median voter, which in this case corresponds to the voter with the median preferences. Expression (1) reveals that the generosity of local social services that a user receives $(a)$ decreases with the tax-price $(p)$ and increases with the preferences for redistribution $(\beta)^{4}$. What we actually observe is per capita spending in social services which amounts to:

$$
g \equiv p \cdot a=p^{\frac{\beta}{\beta-1}} \cdot \beta^{\frac{1}{1-\beta}}
$$

Expression (2) implies that (per capita) spending in social services will be lower: (i) the lower the preferences for redistribution and (ii) the higher the share of the population in social services ${ }^{5}$. Immigration might actually affect spending in social services negatively by these two channels. According to Alesina et al. (2001) and Alesina and Glaeser (2004), more immigration implies more ethnic heterogeneity which can lead to lower preferences for redistribution (lower $\beta$ ). At the same time, as emphasized in Razin et al. (2002), (lowskilled) immigration might increase the cost of income redistribution (higher $p$ ) if it raises the fraction of population in social services.

\section{Data and variables}

\subsection{Data}

Spain is a fiscally decentralized country with three layers of government: central government, 17 regional governments (Comunidades Autónomas) and more than 8,000

\footnotetext{
${ }^{4} \mathrm{~A}$ third channel by which immigration could affect spending in social services is by changing local income and (per capita) tax revenues. This channel is not present in our model given the quasilinear utility function adopted. In our application, this assumption turns out to be not too unrealistic as our findings indicate that immigration does not affect per capita tax revenues. This is probably explained by the fact that local tax bases in Spain are not too sensitive to changes in local income. We return to this issue below.

5 After some algebra one can show that $\frac{d g}{d \beta}=\frac{1}{(1-\beta)^{2}} \cdot p^{\frac{\beta}{\beta-1}} \cdot \beta^{\frac{1}{1-\beta}}\left[\frac{1-\beta}{\beta}+\ln (\beta)-\ln (p)\right]>0$.

Note that the term $(1-\beta) / \beta+\ln (\beta)$ goes from infinity to zero as $\beta$ goes from zero to one, which guarantees that the previous derivative is positive. Following the same reasoning, one can show that $d a / d \beta>0$.
} 
municipalities ${ }^{6}$. We consider municipal government spending in three consecutive terms of office. Specifically, we consider the last full year in each of three legislatures: 1998, 2002 and $2006^{7}$. Unfortunately, detailed budget data for the universe of local governments are not available. Our sample, therefore, is determined by the availability of spending data, taken from a survey on budget outlays conducted yearly by the Spanish Ministry of Economy. This survey is distributed to all municipalities with more than 5,000 inhabitants and a representative sample of the smaller ones. However, some municipalities, especially the smaller ones, do not provide budget data in sufficient detail to define their spending in social services. Additionally, we have to exclude the municipalities of the Basque Country and Navarre since, for historical reasons, these regions have their own fiscal regimes. Eventually, we are able to construct a balanced panel comprising 878 municipalities that accounts for 69 percent of the population in 2006 (excluding that part resident in the Basque Country and Navarre). The sample presents a marked underrepresentation of small municipalities; in fact, none of the 4,102 municipalities with less than one thousand inhabitants is included in our sample, while only 15 percent of those with a population between one and five thousand inhabitants are included. By contrast, 44, 66 and 95 percent of the municipalities with 5-20, 20-100 and $>100$ thousand inhabitants are present in our estimation sample ${ }^{8}$.

\footnotetext{
${ }^{6}$ These coexist with Diputaciones, Comarcas, Consejos Insulares and Cabildos. See Solé-Ollé and SorribasNavarro (2008) for more information on these upper tiers of local government, which play an important role in financing municipal investment through capital grants.

${ }^{7}$ Municipal elections were held in June 1999, May 2003 and May 2007 throughout all Spanish municipalities. Voters choose between several closed party lists. The electoral system is a proportional one, with seats being allocated using the d'Hondt rule with a threshold. The mayor is elected by a majority of the council, which operates as a small representative democracy. We do not use 2010 to avoid the Great recession as local governments' budgets were severely hit.

8 These percentages are also based on 2006 population and municipality figures that exclude the Basque Country and Navarre.
} 


\subsection{Municipal spending in social services}

The public spending of Spanish municipalities represents around 13 percent of total public spending and municipal governments enjoy a large degree of autonomy in decisions regarding spending. Municipal fiscal policies are most likely shaped by the preferences of the native population. First, because, in our period of study, only Spanish, EU and Norwegian citizens can vote in municipal elections ${ }^{9}$; and, second, foreign-born individuals are less politically mobilized than natives. On the one hand, foreign-born who can vote (EU foreign-born Spanish citizens) have a markedly lower voter turnout (around 20 percent, see Durán Muñóz 2011, for details). On the other hand, foreign-born are less active through civic institutions. In fact, in the 1998-2008 period, only 1 percent of the civic organizations were created by immigrants and only 1 percent of their members were foreigners (Aparicio-Gómez and Tornos-Cubillo, 2010).

In 2006, local taxes represented 40 percent of the (aggregate) current revenue of municipal governments, user charges accounted for a further 25 percent and the remainder comprised inter-governmental grants. Several taxes are levied at the municipal level: a property tax, a local business tax, a tax on vehicles, a tax on building activities, and a tax on the sale of land and buildings. Within established limits, which vary by population size, municipalities are free to set their own tax rates. Inter-governmental grants are, by and large, formula-based block grants. They are (virtually) fully distributed on a population basis that establishes different per capita amounts for different population size intervals ${ }^{10}$.

Municipalities are multi-purpose governments with major spending categories corresponding to the traditional responsibilities of local governments excluding education. These spending categories include police and fire protection (on average, 7 percent of total spending), housing, street lighting and cleaning (15 percent), water supply and waste treatment (13 percent), culture and sports (14 percent), local roads and economic

\footnotetext{
${ }^{9}$ However, only Spanish citizens can vote in regional and national elections.

${ }^{10}$ See Bosch and Solé Ollé (2007) for a more complete description.
} 
development programs (15 percent), and general services (20 percent). Health care and education are primarily the responsibility of regional governments and, as a result, municipalities only spend 1 and 4 percent of their budgets, respectively, on these items. Expenditure responsibilities vary according to population size intervals that coincide with those defined in relation to maximum tax rates and per capita grants.

In 2006, 11 percent of aggregate municipal spending was dedicated to social services $^{11}$. These expenditures aim at helping individuals (and households) experiencing economic and/or social problems ${ }^{12}$. These expenditures are targeted at low-income households, the elderly, disabled, sick, unemployed or young persons under vulnerable situations. The services provided (and their importance) depend on the social needs of each municipality. Municipalities provide in-kind transfers, which might include soup kitchens, supervised flats or residences, psychological support, home care services or occupational training courses and programs providing assistance to find a job ${ }^{13}$. They also provide means-tested cash transfers to finance, among others, school meals, summer camps and electricity, gas and water bills. Notice that these programs are clearly among the most redistributive of municipal expenditures, which is why here we focus on this particular spending category.

Table 2 presents summary statistics and the top panel of Figure 1a summarizes the distribution of spending on municipal social services per capita in 2006. All budget variables are expressed in $2006 €$. In that year, the average expenditure on social services programs was $111.5 €$ per capita with a coefficient of variation of 62.4 percent, indicating

\footnotetext{
11 Social services spending corresponds to the expenditure items contained in chapter 3 of the Classificación Funcional del Gasto. The other items correspond to the following chapters: General spending - chapter 1; Police and fire protection - chapter 2; Health - 4.1; Education - 4.2; Housing, street lighting and cleaning - 4.3; Water supply and waste treatment - 4.4; Culture and sports 4.5; while Local roads and economic development is the sum of chapters 5, 6 and 7.

12 These programs do not include unemployment insurance, which is the responsibility of central government.

${ }^{13}$ Some (small) municipalities do not provide all of these services directly but rather buy them from upper tiers of government. Our spending measure includes the costs of these indirect forms of provision.
} 
substantial variation in expenditure across municipalities ${ }^{14}$. In the bottom panel of Figure 1a, we summarize the changes in social services spending between 1998 and 2006. There was an increase in the municipal resources devoted to social services programs during this period (the average increase in our sample is $40 €$ per capita in real terms). This increase coincided with a long period of economic expansion in which the average annual real GDP growth of the Spanish economy was 3.9 percent. Public expenditure also increased at a similar rate. These new resources were partly devoted to provide additional services. In fact, local governments started to provide services demanded by their population that, in principle, were not among their spending responsibilities. Figure $1 \mathrm{~b}$ shows that social services spending as a share of total spending also exhibited substantial variation across municipalities - both in its 2006 level and in its 1998-2006 changes. This variation in the resources devoted to social services reflects the high degree of autonomy enjoyed by Spain's municipalities in their spending decisions. It is also an indication that upper-level governments do not set any minimum standards as regards specific spending programs and that the vast majority of grants received by municipal governments are not ear-marked.

[Insert Table 1]

[Insert Figures 1a and 1b]

\subsection{Spain's immigration wave}

Between 1998 and 2006, Spain experienced a massive increase in its foreign-born population. Most immigrants came to Spain to work attracted by the vigorous economic

\footnotetext{
${ }^{14}$ The Local Government Act assigns different responsibilities to municipalities of different sizes (see Solé-Ollé and Bosch-Roca 2005, for a more complete description). The Act establishes that municipalities with less than 20 thousand inhabitants are not obliged to provide social services. Despite this, many municipalities below this population threshold do provide these services (Mas and Vilalta 2006). In the econometric analyses, we include dummies that account for these legal differences in spending responsibilities.
} 
growth that took place in this period ${ }^{15}$. This wave of immigration is illustrated in Figure 2. The immigration inflows account for roughly 80 percent of total population growth between 1998 and 2006 (almost 5 million inhabitants). The percentage of foreign-born individuals nationwide increased from 2.9 to 10.8 between 1998 and 2006, the period we study. If we focus our attention solely on individuals born outside the EU15 countries, this percentage rises from 1.7 to 8.6. In Table 1 we list the 1998 and 2006 figures for the number and proportion of foreign-born individuals by their country of origin, together with the inflow recorded between these two years. The table shows that the immigration wave was very heterogeneous with the highest inflows originating in Ecuador $(451,326)$, Morocco (416,559), Romania $(394,228)$ and Colombia $(269,141)$.

In our empirical analysis we adopt a somewhat restrictive immigrant definition by excluding individuals born in the EU15 countries $^{16}$. Figure 3 describes the distribution of immigrant density, defined as the percentage of non EU15 individuals in the municipality. The top panel shows the 2006 distribution in our estimation sample, while the bottom panel describes the change in this distribution between 1998 and 2006. The average immigrant density in 2006 was 7.4 while the average 1998-2006 increase was 5.8, reflecting the size of the immigrant influx in this period. Moreover, the interquartile range in the 1998-2006 change was as high as 6.3, highlighting the unequal geographical distribution of immigrant inflows, a feature we exploit in the empirical analysis. The descriptive statistics for the four-year changes in immigrant density that are used in the econometric exercise are provided in the bottom panel of Table 2 .

\footnotetext{
15 Among immigrants entering Spain between 1998 and 2006, the proportion of asylum seekers was 3 percent (OECD-International Migration Database).

${ }^{16}$ There are several reasons to exclude EU15 immigrants. EU15 foreigners might be perceived by natives as ethnically closer than non-EU15 foreigners and are less likely to be social services' users than non-EU15 foreigners. On a more practical note, the availability of rentals in 1991 does not explain the location of EU15 immigrants in the 1998-2006 period as these immigrants are much less dependent on rental housing than non-EU15 immigrants. Since the 2SLS coefficients estimate the effects of interest for the population of compliers, we are unable to estimate the effect of EU15 immigrants on social services spending.
} 


\section{[Insert Figures 2 and 3]}

\section{[nsert Table 2]}

This immigration wave increased ethnic heterogeneity in Spain, a trait that is typically measured in the literature using the fractionalization index. We computed this index at the national level, using country of birth as ethnic background, and found that its value almost quadrupled between 1998 and 2006, rising from 0.06 to $0.2^{17}$. The index can be interpreted as the probability that two randomly drawn individuals from the overall population belong to different ethnic groups.

The average immigrant arriving in this period is relatively low-skilled ${ }^{18}$. As shown above, immigration can also affect redistributive public spending by changing the fraction of the population that uses social services. A significant fraction of immigrants (roughly a third of non EU15 immigrants in 2006) do not hold residence permits. However, in the period we analyze, all immigrants enjoyed access to all municipal services as well as to education and health care (provided by regional governments). To have access to these services, immigrants need only enroll in the municipal register (Padrón Municipal) and, to do so, they do not have to provide proof of their legal status. Thus, to know if immigration raises the fraction of the population that uses social services we need to know if immigrants are over (or under) represented among the population of social services users. Fortunately for us, the Ministry of Health, Social Services and Equality provides (aggregate) data on local social services use by immigrant status. In 2007, the likelihood that an immigrant was using local social services was 40 percent higher than a native ${ }^{19}$. Hence, we

\footnotetext{
17 The fractionalization index is defined as $1-\sum s_{c t}^{2}$, where $s_{c t}$ is the share of population in year $t$ from country $c$. For further details, see Alesina and La Ferrara (2005).

${ }^{18}$ According to the 2011 Census, while 64 (31) percent of natives have, at least, secondary (tertiary) education, this percentage is 55(20) for non-EU immigrants.

${ }^{19}$ Immigrants defined as individuals with a non EU27 nationality. The probability that an individual is a social services' user is 6.6 for EU27 citizens and 9.2 percent for non-EU27 citizens.
} 
expect immigration to affect public spending by increasing both ethnic heterogeneity and the proportion of population using social services.

\section{Empirical analysis}

\subsection{OLS results}

We estimate (variants of) the following specification:

$$
\Delta \text { social services }_{i t}=\beta \cdot \Delta \text { immigrant density }_{i t}+\Delta x_{i t}^{\prime} \varphi+\lambda_{t}+\varepsilon_{i t}
$$

where $\Delta$ social services $_{i t}$ is the change in the (per capita) social services spending in municipality $i$ between two consecutive terms of office, $t$ and $t+4$ (i.e. 1998-2002 and 20022006). Our main explanatory variable, Aimmigrant density ${ }_{i t}$, is the change in the percentage of individuals born outside EU15 countries in the municipality over the same time window, $\lambda_{t}$ is a time fixed effect and $\varepsilon_{i t}$ is an error term. Following the median voter approach developed by Borcherding and Deacon (1972) to estimate the demand for local public services, the vector $\Delta x_{i t}^{\prime}$ reflects contemporaneous changes in control variables capturing differences in fiscal capacity and expenditure needs across municipalities ${ }^{20}$. The Ordinary Least Squares (OLS) results are presented in panel a) of Table 3, where standard errors are clustered at the municipality level. The first column is a regression that contains no control variables (besides time fixed effects). In the second column, we add changes in variables reflecting the fiscal capacity of municipalities, namely, the (per capita) property tax base (the main local tax), dummies for population size intervals $(<5,5-20,20-100,>100$ thousand inhabitants) that identify homogenous municipalities in terms of common maximum tax rates, spending responsibilities and formula-based block grants, and the ratio

\footnotetext{
${ }^{20}$ Note that fiscal capacity and expenditure needs might, in turn, be affected by immigration and, thus, be endogenous. Nevertheless, excluding these controls might also confound the effect of immigration on spending in social services. Reassuringly, the results will be robust to the inclusion of these controls.
} 
between the debt burden of the municipal government and its current revenues. Finally, the third column further includes the relative size of population groups with specific expenditure needs: the percentage of young (under 16 years of age) and old (over 64) individuals and the percentage of 16- to 64-year-olds that are unemployed (see Table 2 for summary statistics and data sources).

[Insert Table 3]

The OLS estimates in Table 3 indicate that the increase in social services spending was lowest in those municipalities experiencing the greatest increases in immigrant density. Specifically, the results in column (1) imply that a percentage point increase in immigrant density reduces (per capita) spending in social services by $1.2 €$. The inclusion of controls that reflect municipal fiscal capacity in column (2) leaves this estimate largely unchanged, suggesting that the effect of immigrant density on social spending is not explained by the fact that immigrants tend to concentrate in municipalities with low tax bases or those that are under fiscal distress. Our estimate of interest also remains unaltered when, in column (3), we further include a set of variables reflecting differences in expenditure needs. Hence, the effect of immigrant density on social services spending that we identify extends beyond the changes in the proportions of young, old, and unemployed individuals in the municipality.

\subsection{Instrument}

Despite having controlled for a comprehensive set of observable changes in social spending determinants, shocks in unobserved spending determinants that might be correlated with shocks in immigrant density could be confounding our estimates. Hence, we resort to an instrumental variables approach. The type of housing available in a city has been found to be an important driver of immigrants' location choices in European 
countries such as Denmark (Damm 2009; Harmon 2014), France (Verdugo 2014) and Italy (Boeri et al. 2015). The instrument that we will use exploits the characteristics of the housing stock in 1991 to predict where the immigrants will locate in the period 1998-2006.

Spain is among the OECD countries where homeownership is more pervasive (Andrews and Caldera-Sánchez 2011). According to the 2001 Census, the homeownership rate was as high as 82 percent. Importantly for our purposes, immigrants are much more likely than natives to be renters; the homeownership rate was 89 (45) percent for natives (immigrants). Our instrument uses the availability of rental housing in 1991 to predict the 1998-2006 location choices of immigrants across Spanish municipalities. To predict immigrant density in year $t$ and municipality $i$ we divide predicted number of immigrants by the population level in 1998, our baseline year.

$$
\overline{\text { immigrant density }_{i t}} \equiv \frac{\overline{\text { immigrants }_{i t}}}{\operatorname{pop}_{i 98}} \equiv \frac{\gamma_{i 1991} \cdot \text { immigrants }_{t}}{\text { pop }_{i 98}}
$$

where $\gamma_{i 1991}$ is the (nationwide) share of 1991 rental units that are located in municipality $i$ in 1991 while immigrants $_{t}$ is the number of (non EU15) foreign-born living in Spain in $t$. Note that the instrument resembles the shift-share instrument pioneered by Altonji and Card (1991) in that the predicted local immigration stock in year $t$ is obtained by multiplying a pre-determined local characteristic with national immigration stocks in year $t^{21}$. However, instead of using early settlement patterns of immigrants as in Altonji and Card (1991), we exploit the availability of appropriate housing for immigrants ${ }^{22}$. In the regressions, we instrument changes in immigrant density $\left(\Delta\right.$ immigrant density $\left._{\text {it }}\right)$ with changes in predicted density defined as:

\footnotetext{
${ }^{21}$ Recent examples of papers using Altonji and Card (1991) type of instruments include Saiz (2007), Cortes (2008), Card (2009), Peri (2012) and González and Ortega (2011, 2013).

${ }^{22}$ In sub-section 4.5, we also report 2SLS results based on the Altonji and Card (1991) strategy.
} 


$$
\overline{\Delta \text { immigrant density }_{\mathrm{it}}}=\frac{\overline{\text { immigrants }_{i t+4}}}{\operatorname{pop}_{i 98}}-\frac{\overline{\text { immigrants }_{i t}}}{\text { pop }_{i 98}}
$$

The cross-sectional variation in the instrument comes from differences in the availability of rentals across cities in 1991. In Table 2 we report the summary statistics of the number of rentals in 1991 per 100 inhabitants in 1998, our baseline year. The coefficient of variation is 78 percent, indicating that there is a fair amount of variation across municipalities in the availability of appropriate housing for immigrants. As a result, the instrument is relevant. The bottom rows of panel b) in Table 3 report the F-test of excluded instruments while the full first-stage estimates appear in columns 1 to 3 in Table A1, deferred to the annex. The F-test of excluded instruments is higher than 60 in all specifications, indicating that the instrument is both relevant and strong (see Stock et al. 2002). That is, municipalities with more available rental housing in 1991 attracted more immigrants when the massive immigration inflow took place (1998-2006). Specifically, a one percentage point increase in predicted immigrant density increases observed immigrant density by 0.2 to 0.3 percentage points.

Instrument validity requires that the availability of rental housing in 1991 must be uncorrelated to municipal characteristics associated with differential time-trends in social services spending. To assess the validity of the exclusion restriction, we report how TwoStage Least Squares (2SLS) estimates are affected by the inclusion of baseline municipality characteristics (measured in 1998) and test if predicted immigrant inflows correlate with pre-treatment (1992-1996) changes in social services spending. We will return to these important issues after presenting and discussing the 2SLS estimates.

A strand of the literature, starting with Borjas (1999), has investigated the "welfare magnet" hypothesis, which claims that welfare generosity attracts welfare-prone individuals 
(welfare-prone immigrants) ${ }^{23}$. This hypothesis raises simultaneity concerns since immigrant density changes would then be the consequence and not the cause of changes in social services spending. Note that the 2SLS estimates should be robust to welfare-induced location decisions. As for the OLS results, the presence of welfare magnets effects would bias our (negative) estimates towards zero and, thus, OLS estimates would underestimate the negative effect of immigrant density on social services spending. More generally, if municipalities that are more tolerant towards immigration happen to spend more in social services, OLS estimates will also be biased towards zero if immigrants are attracted to these more tolerant municipalities ${ }^{24}$.

\subsection{SLS results}

Panel b) in Table 3 reports the 2SLS results and, in terms of control variables, follows the structure of panel a): column (4) only includes time dummies, column (5) also includes variables reflecting fiscal capacity, while in column (6) we further add the expenditure needs variables. The 2SLS results also indicate that municipalities receiving larger immigrant inflows reduced their social services spending per capita. In fact, the 2SLS estimates are larger in absolute value and, as it occurred with the OLS estimates, change very little with the inclusion of local measures of fiscal capacity and expenditure needs. A one percentage point increase in the immigrant share reduces per capita spending in social services by 4 to $5 €$ per capita. The results in column (6) imply that the 6.9 percentage points increase in immigrant density recorded in Spain between 1998 and 2006 (rising from

\footnotetext{
${ }^{23}$ For more recent evidence on the welfare magnets hypothesis, see McKinnish $(2005,2007)$ and Fiva (2009).

${ }^{24}$ In practice, the welfare magnets hypothesis is only one reason to expect differences between OLS and 2SLS estimates. Measurement error in immigrant density could also bias the OLS estimates towards zero. In fact, there is some evidence of measurement error in immigrants' counts, especially in the 1998-2001 period (Fernández-Huertas Moraga et al., 2015). Finally, note that OLS and 2SLS might diverge as 2SLS estimate the effect of interest for 'compliers'. In our application, it would be the effect of changes in immigrant density caused by the availability of rental housing in 1991.
} 
1.7 to 8.6 ) would have caused a reduction in social services spending of $32.5 €$ per capita, which amounts to 29.2 (46.7) percent of the variable's mean (standard deviation) in 2006. Hence, we conclude that immigrant density exerts a significant, and negative, effect on social services spending, both in statistical and economic terms.

As discussed above, immigration can affect public spending in social services by decreasing the preferences for redistribution and by increasing the proportion of the population using social services. Note that our estimates of interest are unaffected when controlling for changes in the fraction of unemployed, young and old individuals in the municipality. To the extent that these variables (especially the fraction of unemployed) are good proxies of the fraction of the population in social services, this result would support the preferences for redistribution channel. Note that a more powerful test would be to directly control for the municipal proportion of the population using social services. Unfortunately, these data are not available at the municipality level. Another possibility would be to measure ethnic fractionalization at the local level and test if it reduces social public spending beyond immigrant density. The problem encountered here is that immigrant density and the fractionalization index are highly collinear in our sample. The correlation between changes in immigrant density and changes in the fractionalization index described in sub-section 3.3 is 0.97 . This reflects that the immigrant inflow that most municipalities received was very similar in terms of its heterogeneity measured by the country of origin of immigrants.

The (geographical) mobility of natives is always a concern when using local data to estimate the effect of immigration on outcomes of the receiving society. In the context of studies that examine wages, natives can react to a supply increase of workers in a city (due to immigration) by moving to another city. Hence, geographical mobility will tend to underestimate the effects of immigration on wages (Borjas, 2003). In our case, mobility could also under-estimate (in absolute value) the effect of immigration on 
social services spending. Native social services users might move to municipalities with higher spending (and lower immigration) and these municipalities could, in turn, respond by reducing spending in social services despite receiving little immigration.

\subsection{Instrument validity and robustness checks}

Our exclusion restriction requires rental housing in 1991 to be uncorrelated to municipal characteristics associated with differential time-trends in social services spending. In Spain, municipalities with a higher percentage of rental housing tend to be relatively large and poor and social services spending might systematically increase more (or less) in those municipalities. In columns (1) and (2) of Table 4 we report the results obtained when including, as additional controls, the 1998 (logged) population size and the 1998 unemployment rate, respectively. We find no impact on the results.

\section{[nsert Table 4]}

An additional test of instrument validity consists of correlating the instrument with (pretreatment) changes in social services spending. Column (1) in Table 5 reports the correlation between changes in social services spending in the 1992-1996 period and the instrument (1998-2002 and 2002-2006 changes in predicted immigrant density are pooled). The results indicate that the instrument is not correlated with pre-treatment changes in social services spending. In contrast, columns (2) and (3) show the corresponding, negative and statistically significant, correlations when contemporaneous measures of the dependent variable are used. Since some observations are missing in the 1992-1996 spending dataset, columns (1) and (2) use the exact same (restricted) sample while column (3) uses the final one with 1,756 observations. Reassuringly, the results in Table 5 suggest that the availability of housing rentals in 1991 does not correlate with pre-treatment changes in social services spending. Since the regressions in Table 5 contain time dummies, note that results in 
column (3) are the reduced-form estimates that would correspond to the structural 2SLS estimates reported in column (4) of Table 3.

\section{[nsert Table 5]}

Table 4 addresses a number of additional robustness checks. In the period we study, immigration inflows drove (aggregate) population growth in Spain. Hence, municipalities experiencing the greatest immigrant density increases might also experience more aggregate population growth. In column (3) of Table 4 we add population growth as an additional control. The results show that our estimates of the effects of immigrant density on social services spending do not merely capture increases in aggregate population.

As explained above, most immigrants came to Spain to work. Hence, our results might be confounded by the fact that immigrants tend to locate in economically prosperous areas and those areas might happen to be reducing social services spending ${ }^{25}$. In column (4) we add municipal employment growth while in column (5) we introduce a measure of (demand-driven) employment growth. Specifically, we use the (shift-share) Bartik's (1991) employment growth predictor which assigns the (nationwide) employment growth rate of each (2-digit) industry to each municipal industry employment in the base year (1998). Reassuringly, the results remain unaltered. Note that these results provide further (indirect) evidence that the instrument used is valid. Indeed, directly accounting for local employment growth does not affect our estimates of interest, suggesting that rental housing in 1991 is independent of subsequent local economic shocks. It is perhaps more surprising that neither changes in the municipal unemployment rate (column (6) in Table 3) nor the changes in municipal employment analyzed here have any direct effect on (per capita) spending in social services. This result might actually be very specific to our context.

\footnotetext{
25 See Amudeo-Dorantes and De la Rica (2010) for some evidence that, between 1999 and 2007, immigrants in Spain sought regions with higher employment rates.
} 
As explained in Section 3, we analyze an economic boom period in which public spending was substantially increased while the unemployment rate was significantly reduced.

Spain, as mentioned before, is a fiscally decentralized country whose regions (Comunidades Autónomas) have considerable autonomy with regards to spending. Hence, some regions might spend more than others on raising the living standards of the needy. To control for these interregional differences, we add regional dummies in column (6) of Table 4. Although this empirical specification only exploits changes in immigrant density and spending patterns within regions, our parameter of interest remains largely unchanged. Due to mean reversion, increases in spending in social services might be higher in municipalities with low initial levels of spending. The presence of mean reversion in spending could be driving our results if those municipalities with low spending in social services in 1998 happened to attract more (or fewer) immigrants in subsequent years. The results of a specification that further controls for the 1998 level of spending in social services reported in column (7) reveal that this is not the case. Indeed, mean reversion in spending does not confound our estimates of interest because there is no correlation between social services spending in 1998 and subsequent increases in immigrant density ${ }^{26}$. Finally, we have also estimated the model re-defining our dependent variable as the change in the logged spending per capita in social services. The results, reported in column (8), indicate that increasing immigrant density by one percentage point decreases spending in social services by 5 percent. Given that, on average, per capital social spending is $111.5 €$, a 5 percent decrease would reduce this spending by $5.5 €$ per capita, which is close to our baseline estimates.

\footnotetext{
${ }^{26}$ Note that, a priory, there is no reason why this correlation should be zero. Empirically, however, the correlation between social services spending in 1998 and subsequent (1998-2002 and 20022006) increases in immigrant density is virtually zero (0.002).
} 


\subsection{SLS results using early settlement patterns of immigrants}

As explained above, since Altonji and Card's (1991) study, there has been a tradition in the literature of using the early settlement patterns of immigrants to construct instruments to estimate the effect of immigration on a range of economic outcomes. For the sake of completeness, we also report 2SLS results using this alternative instrumental variables strategy. Specifically, the predicted density in municipality $i$ in year $t$ becomes:

$$
\overline{\text { immigrant density }_{i t}} \equiv \frac{\overline{\text { immigrants }_{i t}}}{\text { pop }_{i 98}} \equiv \frac{\sum_{c} \eta_{i c 1991} \cdot \text { immigrants }_{c t}}{\not o p_{i 98}}
$$

where $\eta_{i c 1991}$ is the (nationwide) share of foreign-born individuals that were living in municipality $i$ from country $c$ in 1991 whereas immigrants it $_{\text {in }}$ is the number of foreign-born from country $c$ living in Spain in $t$. We then use expression (5) to construct our instrument which reflects changes in predicted immigrant densities. The estimates are shown in Table 6 while the full first-stage results are deferred to panel b) of Table A1.

[nsert Table 6]

The results obtained are close to our baseline results that exploited the availability of appropriate housing for immigrants. However, the instrument turns out to be relatively weak as evidenced by the F-test of excluded instrument tests that are just above 10. In fact, the F-test become even smaller (and the instrument weaker) when the additional controls considered in Table 4 are further included. The limited relevance of the early settlement patterns of immigrants is likely to reflect the low presence of foreign-born population in Spain in 1991 when only 1.1 percent of the population was born in non EU15 countries. In any case, it is reassuring that the results using this more conventional IV strategy yield qualitatively similar results. 


\subsection{Results for other public expenditure outcomes}

One concern is that immigration changes per capita tax revenues, which in turn, could change the municipalities' spending patterns. Thus, we estimate the effect of immigrant density on per capita tax revenues in the first row of Table 7 . The results indicate that immigration does not affect per capita tax revenues of local governments. In fact, this is not too surprising given that local governments do not tax local income. The main local tax is the property tax and property tax bases are very seldom reassessed in Spain ${ }^{27}$. In the second row, we estimate the effect of immigrant density on overall spending. The results also indicate that immigration does not affect overall per capita spending of local governments, either. This result, coupled with the results of Tables 3 and 4, imply that immigration must reduce the share spent in social services. In the third row of Table 7 we directly estimate the effect of immigration on the share of total spending devoted to social services. The results indicate that a one percentage point increase in immigrant density reduces social services spending by 0.4 percentage points. Given that, on average, per capita spending is $1,211 €$, a one percentage point increase in immigrant density would reduce per capita spending in social services by $4.1 €$. This figure is very close to our baseline results and corroborates that our results are not driven by changes in overall public spending. To analyze if there is a specific spending component that systematically increases with immigration, we estimate the effect of immigration on the per capita spending in the eight other categories that make up total spending. The results are shown at the bottom of Table7. We find a positive effect for the education spending category but this is not a robust result $\mathrm{t}^{28}$. Overall, we find no robust effect of immigrant density on any of the spending items considered. This suggests that the resources diverted from social services do not systematically concentrate in any of the remaining spending categories.

\footnotetext{
27 According to Dirección General del Catastro, between 1998 and 2006, 77\% of municipalities did not reassess the property tax base.

${ }^{28}$ For instance, it completely vanishes if we include regional dummies.
} 


\section{[nsert Table 7]}

\section{Concluding remarks}

Spain has recently received a massive inflow of (mostly low-skilled) immigrants in a very short period of time. We exploit the uneven geographical distribution of immigrant inflows across Spanish municipalities to estimate the effect of changes in immigrant density on changes in local spending in social services. In order to overcome the potential correlation between shocks in immigrant density and shocks in social services spending, we resort to an instrumental variables approach that exploits the distribution of rental housing in 1991 to predict the location choices of immigrants in the period 1998-2006. The estimates of our preferred specification indicate that the aggregate increase in immigrant density for the period 1998-2006 (6.9 percentage points) led to a fall in municipal social services spending of $32.5 €$ per capita, which amounts to 29.2 percent of the variable's mean in 2006 . This result is not driven by changes in the overall budget attributable to immigration. In fact, we find no effect of immigration on the size of local governments. Note that this result might not hold for the overall public sector since national governments have a much larger tax autonomy than local governments.

There are two theories relating immigration to income redistribution. First, as stressed by Alesina and Glaeser (2004), immigration increases ethnic heterogeneity which, in turn, can reduce the preferences for income redistribution. Second, (low-skilled) immigration increase the cost of redistribution thereby reducing the demand for redistributive public spending (Razin et al. 2002). Our empirical results support the prediction of these theories and suggest that the effect of immigration on income redistribution might be one important channel through which immigration affects receiving economies. 


\section{Acknowledgments}

We wish to thank the Editor, two anonymous referees, Pere Arqué-Castells, George Borjas, Per-Anders Edin, Joan Llull, Leah Platt-Boustan, Joshua Gottlieb, Assaf Razin and Jorge de la Roca for useful comments and suggestions. We acknowledge financial support from the Instituto de Estudios Fiscales. We are also grateful to the Ministerio de Economía y Competitividad -ECO2013-41310 (Jofre-Monseny and Vázquez-Grenno) and ECO201568311-R (Sorribas-Navarro), and Generalitat de Catalunya - 2014SGR420 (Jofre-Monseny, Sorribas-Navarro and Vázquez-Grenno).

\section{References}

Alesina, A., Baqir, R., Easterly, W., 1999. Public goods and ethnic division. Quarterly Journal of Economics 114, 1,243-1,284.

Alesina, A., Glaeser, E.L., 2004. Fighting poverty in the US and Europe: A world of difference. Oxford University Press, Oxford and New York.

Alesina, A., Glaeser, E.L., Sacerdote, B., 2001. Why doesn't the United States have a European-style welfare state? Brookings Papers on Economic Activity 2, 187-254.

Alesina, A., La Ferrara, E., 2005. Ethnic diversity and economic performance. Journal of Economic Literature 43, 762-800.

Amuedo-Dorantes, C., De la Rica, S., 2010. Immigrants' responsiveness to labor market conditions and their impact on regional employment disparities: Evidence from Spain. SERIEs 1, 387-409.

Altonji, J.G., Card, D., 1991. The effects of immigration on the labor market outcomes of less-skilled natives, in Abowd, J.M., Freeman, R.B. (Eds), Immigration, Trade, and the Labor Market, University of Chicago Press, Chicago.

Andrews, D., Caldera-Sánchez, A., 2011. The evolution of homeownership rates in selected OECD countries: Demographic and public policy influences. OECD Journal: Economic Studies, vol. 2011/1. 
Aparicio-Gómez, R., Tornos-Cubillo, A., 2010. Las asociaciones de inmigrantes en España. Una visión de conjunto, Documentos del Observatorio Permanente de la Inmigración, n.26. Ministerio de Trabajo e Inmigración.

Bartik, T., 1991. Who benefits from state and local economic development policies? Kalamazoo, W.E. Upjohn Institute for Employment Research, MI.

Boeri, T., De Philippis, M., Patacchini, E., Pellizzari, M., 2015. Immigration, housing discrimination and employment. The Economic Journal 125 (586), F82-F114.

Borcherding, T.E., Deacon, R.T., 1972. The demand for the services of non-federal governments. American Economic Review 62, 891-901.

Borjas, G., 1999. Immigration and welfare magnets. Journal of Labor Economics 17, 607-637.

Borjas, G., 2003. The Labor Demand Curve is Downward Sloping: Reexamining the Impact of Immigration on the Labor Market. Quarterly Journal of Economics 118, 13351374.

Bosch, N., Solé-Ollé, A., 2007. Yardstick competition and the political costs of raising taxes: An empirical analysis of Spanish municipalities. International Tax and Public Finance 14, 71-92.

Card, D., 2009. Immigration and Inequality. American Economic Review 99, 1-21.

Chiswick, B.R., Miller P.W., (Eds.) 2014. Handbook of the economics of international migration v1B, North-Holland, Amsterdam.

Cortes, P., 2008. The effect of low-skilled immigration on U.S. prices: Evidence from CPI Data. Journal of Political Economy 116, 381-42.

Dahlberg, M., Edmark, K., Lundqvist, H., 2012. Ethnic diversity and preferences for redistribution. Journal of Political Economy 120, 41-76.

Damm, A., 2009. Determinants of recent immigrants' location choices: quasiexperimental evidence. Journal of Population Economics 22, 145-174. 
Durán Muñoz, R., 2011. Fuerza y efecto potenciales del voto de los inmigrantes. Elecciones municipales españolas de mayo de 2007. Revista de Estudios Políticos (nueva época) $152,115-141$.

Fernández-Huertas Moraga, J., Ferrer, A., Saiz, A., 2015. Immigrant Locations and Native Residential Preferences in Spain: New Ghettos?, mimeo.

Fiva, J.H., 2009. Does welfare policy affect residential choices? An empirical investigation accounting for policy endogeneity. Journal of Public Economics 93, 529-540.

Gerdes, C., 2011. The impact of immigration on the size of government: Empirical evidence from Danish municipalities. Scandinavian Journal of Economics 113, 74-92.

González, L., Ortega, F., 2011. How do very open economies adjust to large immigration flows? Evidence from Spanish regions. Labour Economics 18, 57-70.

González, L., Ortega, F., 2013. Immigration and housing booms: Evidence from Spain. Journal of Regional Science 53, 37-59.

Harmon, N., 2014. Immigration, ethnic diversity and political outcomes: Evidence from Denmark. University of Copenhagen, mimeo.

Kerr, P.S., Kerr, W.R., 2011. Economic impacts of immigration: A survey. Finnish Economic Papers 24, 1-32.

Lewis, E., Peri, G., 2015. Immigration and the economy of cities and regions, in Duranton, G., Henderson, V., Strange, W. (Eds.), Handbook of Regional and Urban Economics volume 5, North-Holland, Amsterdam.

Lind, J.T., 2007. Fractionalization and the size of government. Journal of Public Economics 91, 51-76.

Luttmer, E., 2001. Group loyalty and the taste for redistribution. Journal of Political Economy 109, 500-528.

Mas, D., Vilalta, M., 2006. El gasto no obligatorio de los municipios españoles. Federación Española de Municipios y Provincias (FEMP). 
McKinnish, T., 2005. Importing the poor: Welfare magnetism and cross-border migration. Journal of Human Resources 40, 57-76.

McKinnish, T., 2007. Welfare-induced migration at state borders: New evidence from micro-data. Journal of Public Economics 91, 437-450.

Peri, G., 2012. The effect of immigration on productivity: Evidence from U.S. States. Review of Economics and Statistics 94, 348-358.

Razin, A., Sadka, E., Swagel, P., 2002. Tax burden and migration: a political economy theory and evidence. Journal of Public Economics 85, 167-190.

Razin, A., 2013. Migration into de welfare state: tax and migration competition. International Tax and Public Finance 20, 548-563.

Ribar, D.C., Wilhelm, M.O., 1999. The demand for welfare generosity. The Review of Economics and Statistics 81, 96-108.

Saiz, A., 2007. Immigration and housing rents in American cities. Journal of Urban Economics 61, 345-371.

Senik, C., Stichnotch, H., Van der Straeten, K., 2009. Immigration and natives' attitudes towards the welfare state: Evidence from the European Social Survey. Social Indicators Research 91, 345-370.

Solé-Ollé, A., Bosch-Roca, N., 2005. On the Relationship between authority size and the costs of providing local services: Lessons for the design of intergovernmental transfers in Spain. Public Finance Review 33, 343-384.

Solé-Ollé, A., Sorribas-Navarro, P., 2008. The effects of partisan alignment on the allocation of intergovernmental transfers. Differences-in-differences estimates for Spain. Journal of Public Economics 92, 2,302-2,319.

Speciale, B., 2012. Does immigration affect public education expenditures? Quasiexperimental evidence. Journal of Public Economics 96, 773-783. 
Stock, J.H., Wright, J.H., Yogo, M., 2002. A Survey of weak instruments and weak identification in Generalized Method of Moments. Journal of Business and Economic Statistics 20, 518-529.

Verdugo, G., 2016. Public housing magnets: Public housing supply and immigrants’ location choices. Journal of Economic Geography 16(1), 237-265. 
Table 1. Individuals by country of origin

\begin{tabular}{|c|c|c|c|c|c|}
\hline \multirow[b]{2}{*}{ Country } & \multicolumn{2}{|c|}{1998} & \multicolumn{2}{|c|}{2006} & \multirow{2}{*}{$\begin{array}{c}1998-2006 \\
\text { level }\end{array}$} \\
\hline & level & percentage & level & percentage & \\
\hline Total Foreign-born & $1,173,767$ & $100.00 \%$ & $4,873,622$ & $100.00 \%$ & $3,663,855$ \\
\hline Ecuador & 5,315 & $0.45 \%$ & 456,641 & $9.37 \%$ & 451,326 \\
\hline Morocco & 189,402 & $16.14 \%$ & 605,961 & $12.43 \%$ & 416,559 \\
\hline Romania & 3,042 & $0.26 \%$ & 397,270 & $8.15 \%$ & 394,228 \\
\hline Colombia & 17,828 & $1.52 \%$ & 286,969 & $5.89 \%$ & 269,141 \\
\hline Argentina & 60,968 & $5.19 \%$ & 271,444 & $5.57 \%$ & 210,476 \\
\hline Bolivia & 2,568 & $0.22 \%$ & 140,740 & $2.89 \%$ & 138,172 \\
\hline Bulgaria & 1,539 & $0.13 \%$ & 100,763 & $2.07 \%$ & 99,224 \\
\hline Peru & 26,805 & $2.28 \%$ & 123,464 & $2.53 \%$ & 96,659 \\
\hline China & 11,995 & $1.02 \%$ & 104,789 & $2.15 \%$ & 92,794 \\
\hline Venezuela & 44,211 & $3.77 \%$ & 124,851 & $2.56 \%$ & 80,640 \\
\hline Brazil & 19,074 & $1.63 \%$ & 93,396 & $1.92 \%$ & 74,322 \\
\hline Ukraine & 581 & $0.05 \%$ & 69,359 & $1.42 \%$ & 68,778 \\
\hline Dominican Rep. & 21,556 & $1.84 \%$ & 87,111 & $1.79 \%$ & 65,555 \\
\hline Uruguay & 15,500 & $1.32 \%$ & 76,635 & $1.57 \%$ & 61,135 \\
\hline EU15 & 479,518 & $40.85 \%$ & 991,511 & $20.34 \%$ & 511,993 \\
\hline Other countries & 273,865 & $23.33 \%$ & 942,718 & $19.34 \%$ & 668,853 \\
\hline Total Population & $39,852,650$ & & $44,708,964$ & & $4,856,314$ \\
\hline
\end{tabular}

Source: Statistics Spain (INE). 
Table 2. Descriptive statistics

\begin{tabular}{|c|c|c|c|c|}
\hline Cross section, $2006(\mathrm{~N}=878)$ & Mean & St. Dev. & Min & Max \\
\hline \multicolumn{5}{|l|}{ Social Services spending } \\
\hline Social Services spending (€ per capita) & 111.48 & 69.62 & 0.09 & 645.85 \\
\hline Social Services spending (Share of total spending) & 11.84 & 7.26 & 0.01 & 44.41 \\
\hline Total spending ( $€$ per capita) & $1,012.11$ & 427.28 & 340.83 & $4,880.09$ \\
\hline Tax revenues ( $€$ per capita) & 269.70 & 150.35 & 43.26 & 1516.39 \\
\hline \multicolumn{5}{|l|}{ Immigrant density } \\
\hline Immigrant density (percentage) & 7.39 & 5.343 & 0.046 & 35.007 \\
\hline$\overline{\text { Immigrant density (percentage) }}$ & 8.23 & 6.43 & 0.17 & 72.87 \\
\hline Rentals in 1991 (per 100 inbabitants in 1998) & 5.14 & 4.02 & 0.11 & 45.48 \\
\hline \multicolumn{5}{|l|}{ Control variables } \\
\hline Property tax base (€ per capita) & 21,191 & 14,114 & 3,163 & 222,242 \\
\hline Debt burden (percentage) & 6.58 & 6.63 & 0.00 & 63.07 \\
\hline Young (percentage $<16$ years old) & 14.61 & 2.77 & 3.35 & 23.76 \\
\hline Old (percentage $>64$ years old) & 17.98 & 5.54 & 3.98 & 40.22 \\
\hline Unemployment rate (percentage) & 12.07 & 6.98 & 1.32 & 48.11 \\
\hline \multicolumn{5}{|l|}{ Changes, 1998-2002 \& 2002-2006 $(\mathrm{N}=1,756)$} \\
\hline \multicolumn{5}{|l|}{ Social Services spending } \\
\hline$\Delta$ Social Services spending ( $€$ per capita) & 19.95 & 48.79 & -359.21 & 575.23 \\
\hline$\Delta$ Social Services spending (percentage points) & 0.87 & 5.24 & -29.42 & 35.00 \\
\hline$\Delta$ Total spending (€per capita) & 125.33 & 274.29 & $-1,698.81$ & $2,356.21$ \\
\hline$\Delta$ Tax revenues ( $€$ per capita) & 19.66 & 51.23 & -420.48 & 414.67 \\
\hline \multicolumn{5}{|l|}{ Immigrant density } \\
\hline$\Delta$ Immigrant density (percentage points) & 2.92 & 2.69 & -2.70 & 22.29 \\
\hline$\Delta \overline{\text { Immigrant density }(\text { percentage) }}$ & 3.39 & 2.83 & 0.05 & 36.92 \\
\hline \multicolumn{5}{|l|}{ Control variables } \\
\hline$\Delta$ Property tax base (€ per capita) & -106 & 4,994 & $-76,828$ & 59,276 \\
\hline$\Delta$ Debt burden (percentage points) & -1.32 & 8.60 & -75.81 & 68.05 \\
\hline$\Delta$ Young (percentage points) & -1.27 & 2.03 & -27.68 & 9.12 \\
\hline$\Delta O l d$ (percentage points) & 0.61 & 1.73 & -6.51 & 8.75 \\
\hline$\Delta$ Unemployment rate (percentage points) & -1.11 & 3.62 & -15.66 & 13.44 \\
\hline
\end{tabular}

Sources: Spending, grants and debt burden (interests plus principal payments over current revenues) data from Spanish Ministry of Economics. Social services spending corresponds to chapter 3 of the Classificacion Funcional del Gasto. Share of young and old from Padrón Municipal. Property tax base from the Cadastre register. (Overlined) immigrant densities are predicted densities as described in main text. Unemployment rate based on registered unemployed of individuals aged 16-64. All variables in $€$ per capita are expressed in constant prices of 2006 . 
Table 3. The effect of immigrant density on social services spending. Baseline results

\begin{tabular}{|c|c|c|c|c|c|c|}
\hline & \multicolumn{3}{|c|}{ a) OLS estimates } & \multicolumn{3}{|c|}{ b) 2SLS estimates } \\
\hline & (1) & (2) & (3) & (4) & (5) & (6) \\
\hline$\Delta$ Immigrant density & $\begin{array}{c}-1.191 * * * \\
(0.402)\end{array}$ & $\begin{array}{c}-1.189 * * * \\
(0.418)\end{array}$ & $\begin{array}{c}-1.229 * * * \\
(0.438)\end{array}$ & $\begin{array}{c}-4.096^{* * *} \\
(1.586)\end{array}$ & $\begin{array}{c}-4.850^{* *} \\
(2.024)\end{array}$ & $\begin{array}{c}-4.731 * * \\
(2.071)\end{array}$ \\
\hline Fiscal capacity & & & & & & \\
\hline$\Delta$ Property tax base & & $\begin{array}{c}238.766 \\
(346.398)\end{array}$ & $\begin{array}{c}241.396 \\
(352.083)\end{array}$ & & $\begin{array}{l}-133.882 \\
(383.471)\end{array}$ & $\begin{array}{c}-17.618 \\
(369.874)\end{array}$ \\
\hline$\Delta$ Debt burden & & $\begin{array}{c}-0.299 * * \\
(0.137)\end{array}$ & $\begin{array}{c}-0.301^{* *} \\
(0.138)\end{array}$ & & $\begin{array}{c}-0.326^{* *} \\
(0.136)\end{array}$ & $\begin{array}{c}-0.328^{* *} \\
(0.139)\end{array}$ \\
\hline $\begin{array}{l}\Delta \text { Municipality size } \\
\text { intervals }\end{array}$ & No & Yes & Yes & No & Yes & Yes \\
\hline Expenditure needs & & & & & & \\
\hline$\Delta$ Young $(<16$ years old $)$ & & & $\begin{array}{c}-1.491 * * \\
(0.738)\end{array}$ & & & $\begin{array}{c}-1.911 * * \\
(0.844)\end{array}$ \\
\hline$\Delta O l d(>64$ years old $)$ & & & $\begin{array}{l}-0.600 \\
(1.029)\end{array}$ & & & $\begin{array}{l}-3.631 * \\
(1.952)\end{array}$ \\
\hline$\Delta$ Unemployment rate & & & $\begin{array}{l}0.162 \\
(0.461)\end{array}$ & & & $\begin{array}{c}0.197 \\
(0.461)\end{array}$ \\
\hline $\begin{array}{l}\text { F-test excluded } \\
\text { instruments }\end{array}$ & & & & 80.84 & 62.04 & 69.98 \\
\hline
\end{tabular}

\begin{tabular}{lrlllll}
\hline Observations & 1,756 & 1,756 & 1,756 & 1,756 & 1,756 & 1,756 \\
\hline
\end{tabular}

Notes: The dependent variable is the change in social services spending per capita. Pool of 1998-2002 and 2002-2006 observations. Robust standard errors in parenthesis clustered at the municipality level. ${ }^{* * *}$ denotes statistical significance at the $1 \%$ level, ${ }^{* *}$ at the $5 \%$ level, and ${ }^{*}$ at the $10 \%$ level. All regressions include time dummies. Municipality size intervals are $<5,5-20,20-50,50-100$ and $>100$ thousand inhabitants. 
Table 4. The effect of immigrant density on social services spending. 2SLS estimates. Robustness checks

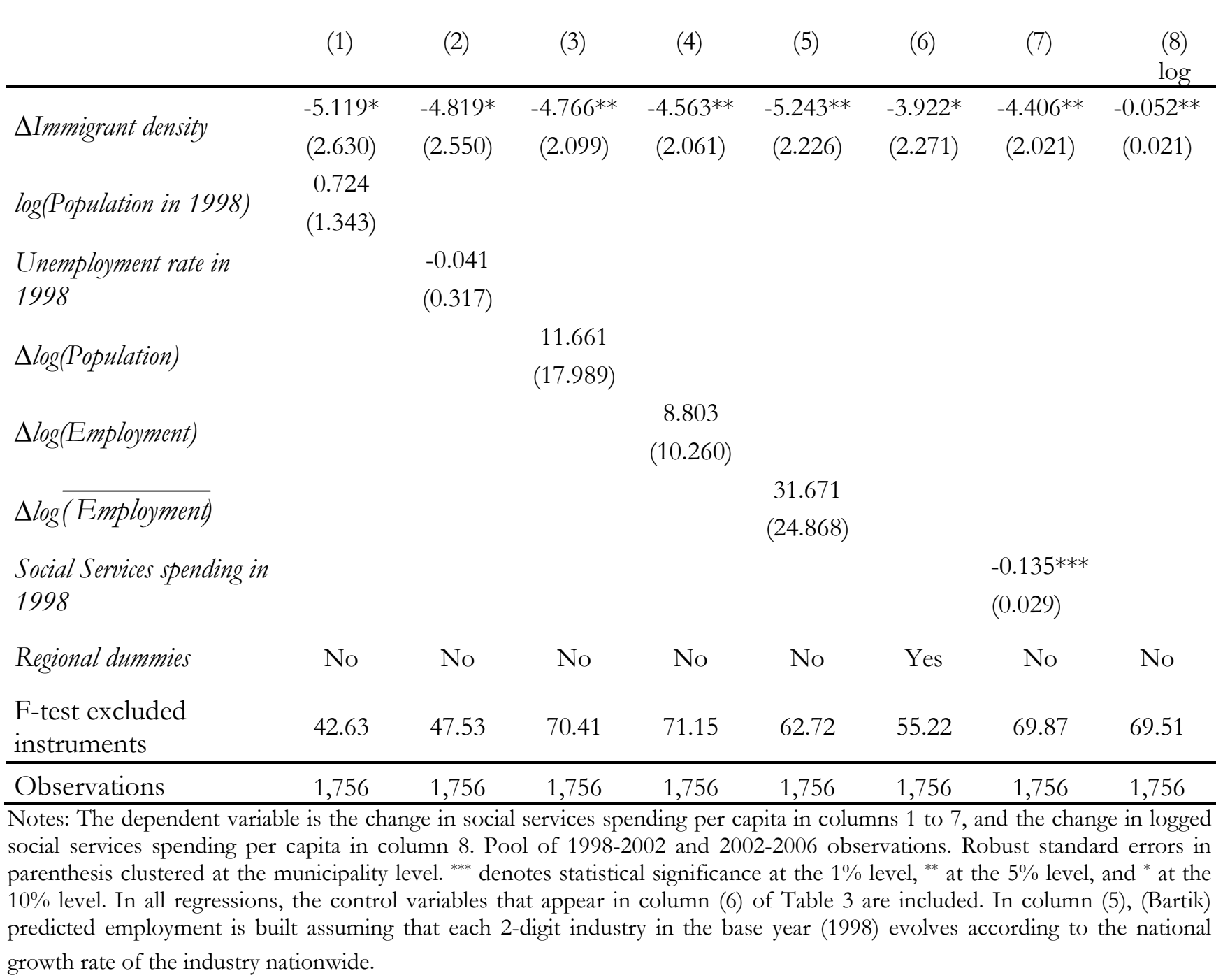


Table 5. Pre-treatment (1992-1996) changes in per-capita spending

\begin{tabular}{lccc}
\hline & $\mathbf{1 9 9 2 - 1 9 9 6}$ & $\mathbf{1 9 9 8 - 2 0 0 2}$ & $\mathbf{1 9 9 8 - 2 0 0 2}$ \\
& $(1)$ & $\mathbf{2 0 0 2 - 2 0 0 6}$ & $\mathbf{2 0 0 2 - 2 0 0 6}$ \\
& & $(2)$ & $(3)$ \\
\hline & & & \\
\cline { 1 - 1 } & & $-1.455^{* * *}$ & $-1.103^{* * *}$ \\
& -0.458 & $(0.448)$ & $(0.414)$ \\
\hline Obsmigrant density & $(0.535)$ & & 1,756 \\
\hline
\end{tabular}

Notes: The dependent variable is the change in social services spending per capita. Column (1): 1992-1996 observations. Columns (2) and (3): Pool of 1998-2002 and 2002-2006 observations. In column (2) we use the restricted sample of column (1). All regressions include time dummies. Robust standard errors in parenthesis clustered at the municipality level; ${ }^{* * *}$ denotes statistical significance at the $1 \%$. 
Table 6. 2SLS estimates based on immigrants' early settlement patterns

\begin{tabular}{lccc}
\hline & $(1)$ & $(2)$ & $(3)$ \\
\hline \multirow{2}{*}{ Immigrant density } & $-3.535^{*}$ & $-4.098^{*}$ & -3.705 \\
& $(1.978)$ & $(2.434)$ & $(2.261)$
\end{tabular}

Fiscal capacity

$\Delta$ Property tax base

$-57.338 \quad 58.271$

$(415.659)$

$\Delta$ Debt burden

$-0.320^{* *}$

$-0.320 * *$

$\Delta$ Municipality size intervals

No

(0.134)

(0.136)

Yes

Yes

\section{Expenditure needs}

$\Delta$ Young $(<16$ years old $)$

$\Delta \operatorname{Old}(>64$ years old $)$

0.187

$\Delta U$ Unemployment rate

F-test excluded instruments

10.15

10.11

10.12

Observations

1,756

1,756

1,756

Notes: The dependent variable is the change in social services spending per capita. Pool of 1998-2002 and 2002-2006 observations. Robust standard errors in parenthesis clustered at the municipality level. ** denotes statistical significance at the 5\% level, and * at the $10 \%$ level. All regressions include time dummies. Municipality size intervals are $<5,5-20,20-50,50-100$ and $>100$ thousand inhabitants. 
Table 7. The effects of immigrant density on total spending and on spending in different categories. 2SLS estimates

\begin{tabular}{|c|c|}
\hline & $\Delta$ Immigrant density \\
\hline (1) Tax revenues & $\begin{array}{l}-5.179 \\
(3.263) \\
\end{array}$ \\
\hline (2) Total spending & $\begin{array}{c}2.709 \\
(12.034)\end{array}$ \\
\hline (3) Share of total spending in social services & $\begin{array}{c}-0.405^{* *} \\
(0.165) \\
\end{array}$ \\
\hline Other expenditure categories & \\
\hline (3) General services & $\begin{array}{l}-3.730 \\
(3.341)\end{array}$ \\
\hline (4) Police and fire protection & $\begin{array}{c}0.787 \\
(1.002) \\
\end{array}$ \\
\hline (5) Health & $\begin{array}{c}2.768 \\
(3.434) \\
\end{array}$ \\
\hline (6) Education & $\begin{array}{l}2.816^{* *} \\
(1.425) \\
\end{array}$ \\
\hline (7) Housing, street lighting and cleaning & $\begin{array}{l}-7.328 \\
(5.443) \\
\end{array}$ \\
\hline (8) Water supply and waste treatment & $\begin{array}{l}-1.150 \\
(3.433) \\
\end{array}$ \\
\hline (9) Culture and sports & $\begin{array}{c}7.019 \\
(5.270)\end{array}$ \\
\hline (10) Local roads and economic development & $\begin{array}{l}-1.808 \\
(4.940)\end{array}$ \\
\hline
\end{tabular}

Notes: The dependent variables are changes in per capita spending. Pool of 1998-2002 and 20022006 observations $(\mathrm{N}=1,756)$. Robust standard errors in parenthesis clustered the municipality level. ${ }^{* *}$ denotes statistical significance at the $5 \%$ level. In all regressions, the control variables present in column (6) of Table 3 are included. 
Figure 1a. Distribution of (per capita) spending in social services across municipalities
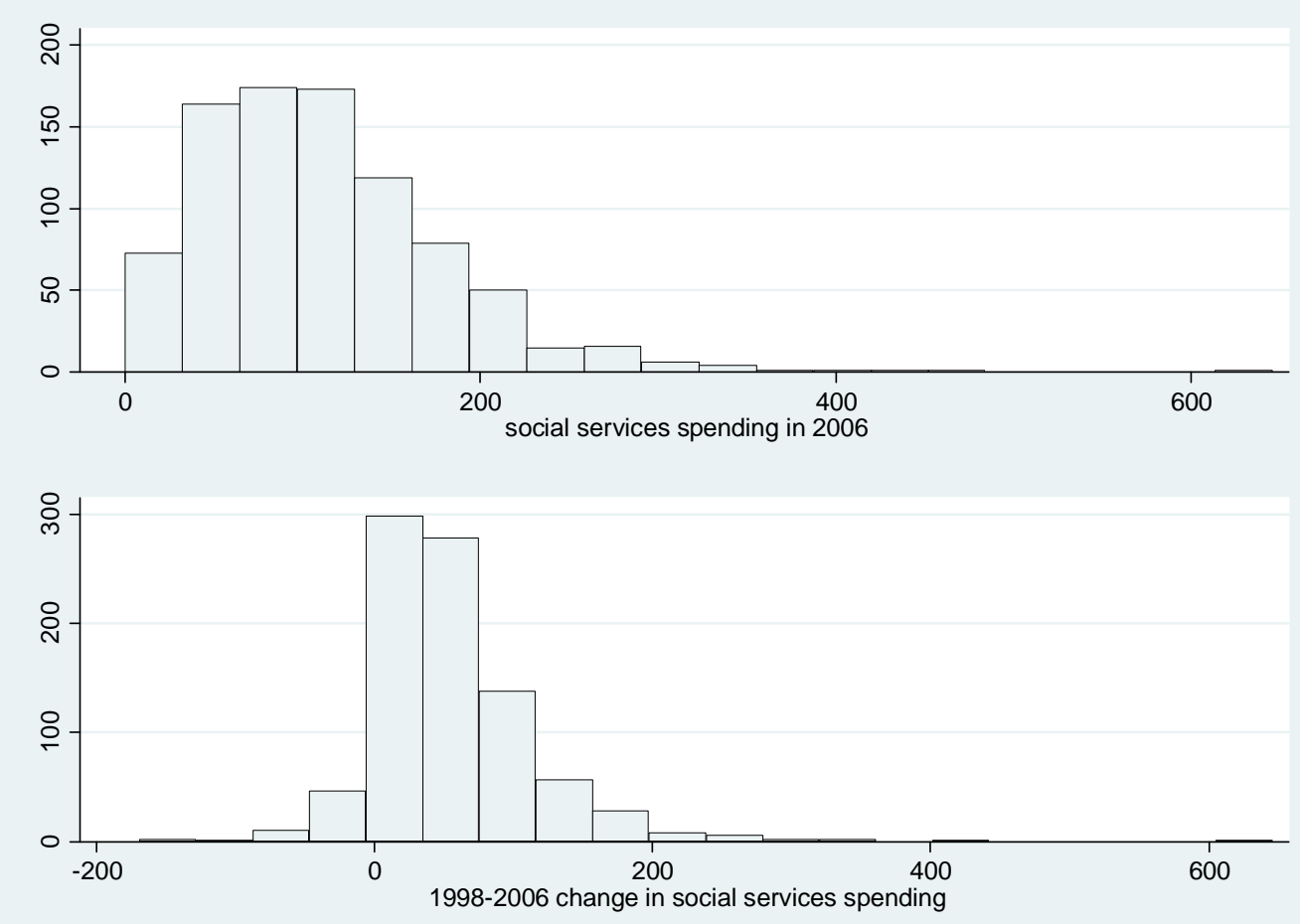

Notes: Frequency in the vertical axis. The number of observations is 878 which corresponds to the estimation sample.

Figure 1b. Distribution of social services spending as a percentage of total spending across municipalities

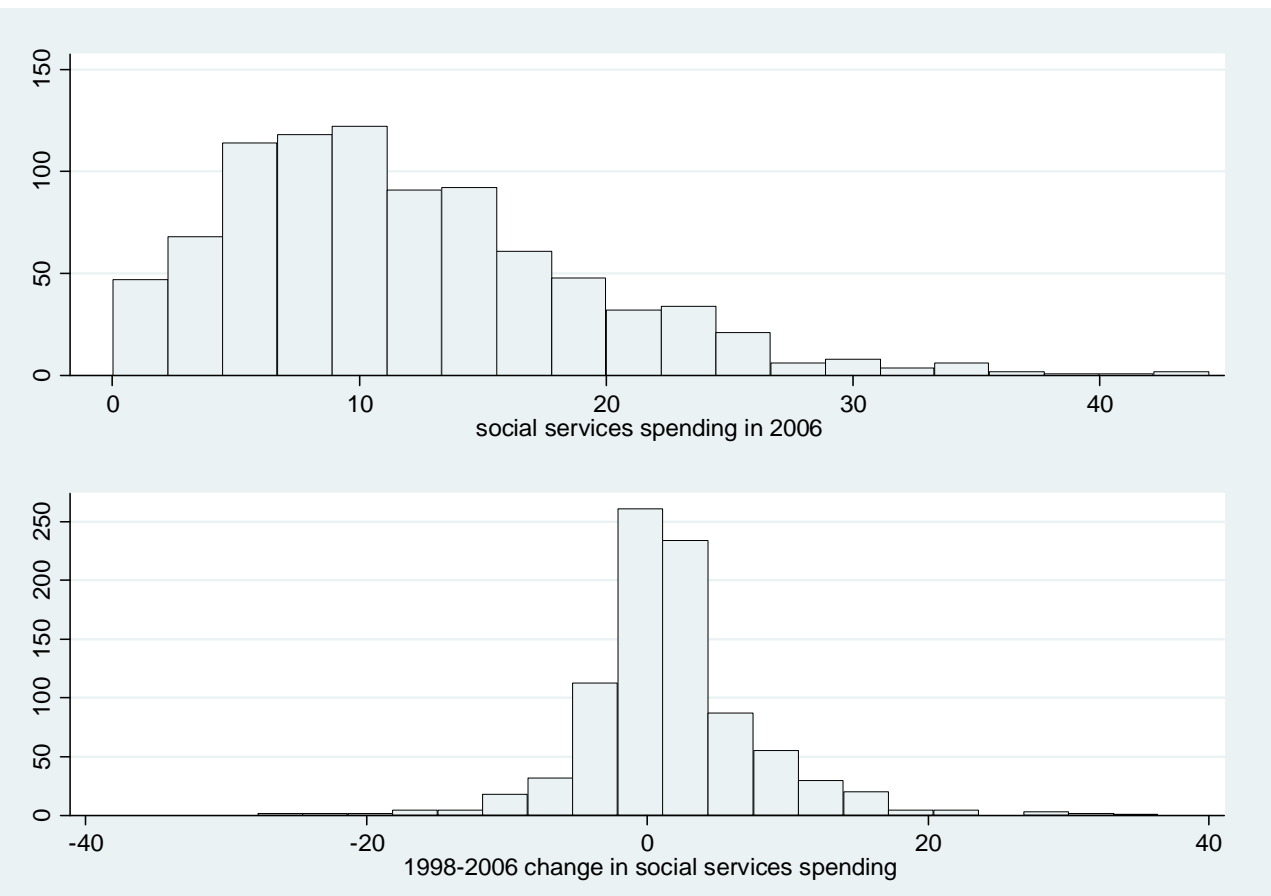

Notes: Frequency in the vertical axis. The number of observations is 878 which corresponds to the estimation sample. 
Figure 2. The Spanish immigration wave: Nationwide population levels and shares
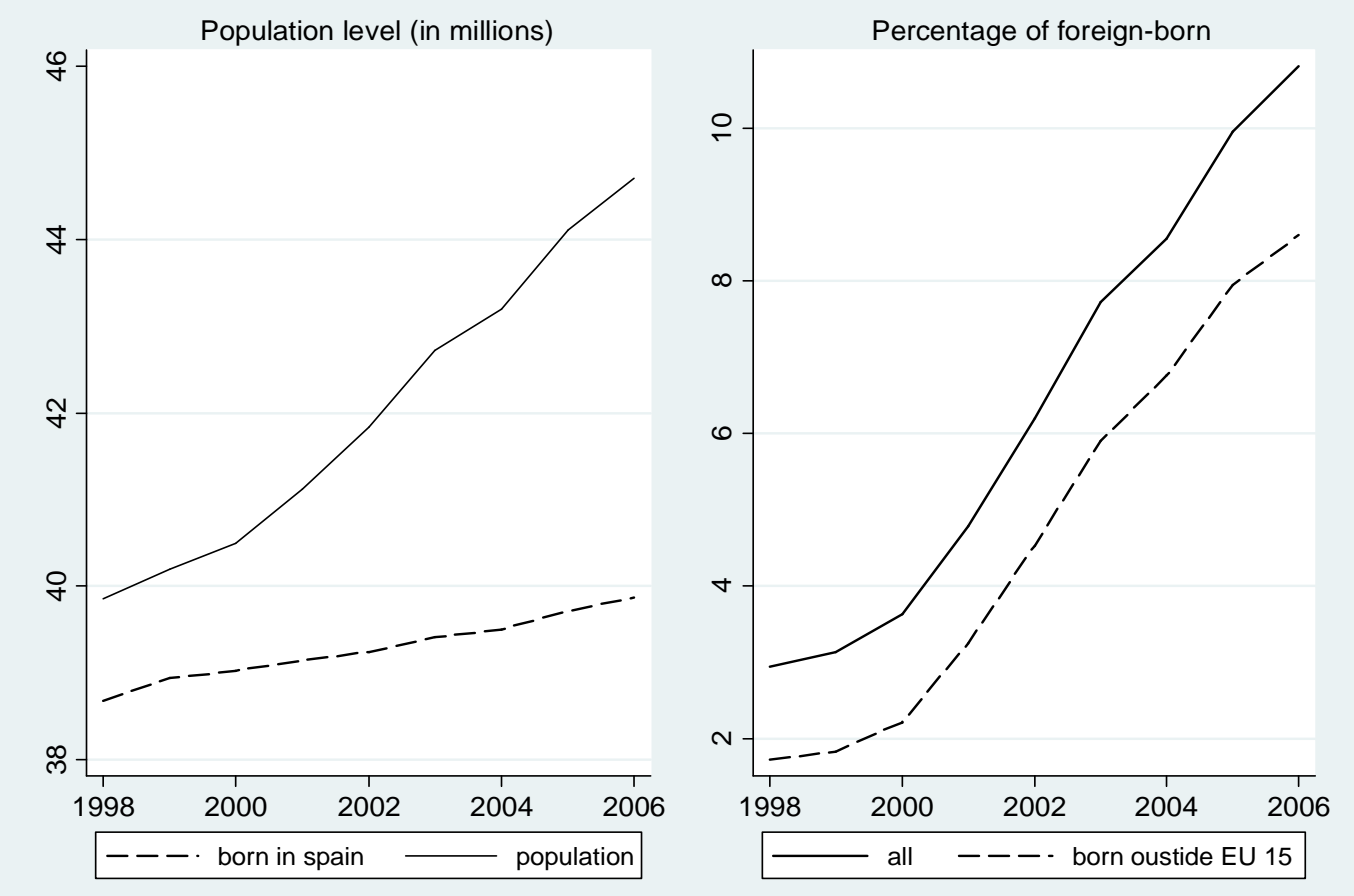

Source: Statistics Spain (INE). 
Figure 3. Distribution of the percentage of individuals born outside EU15
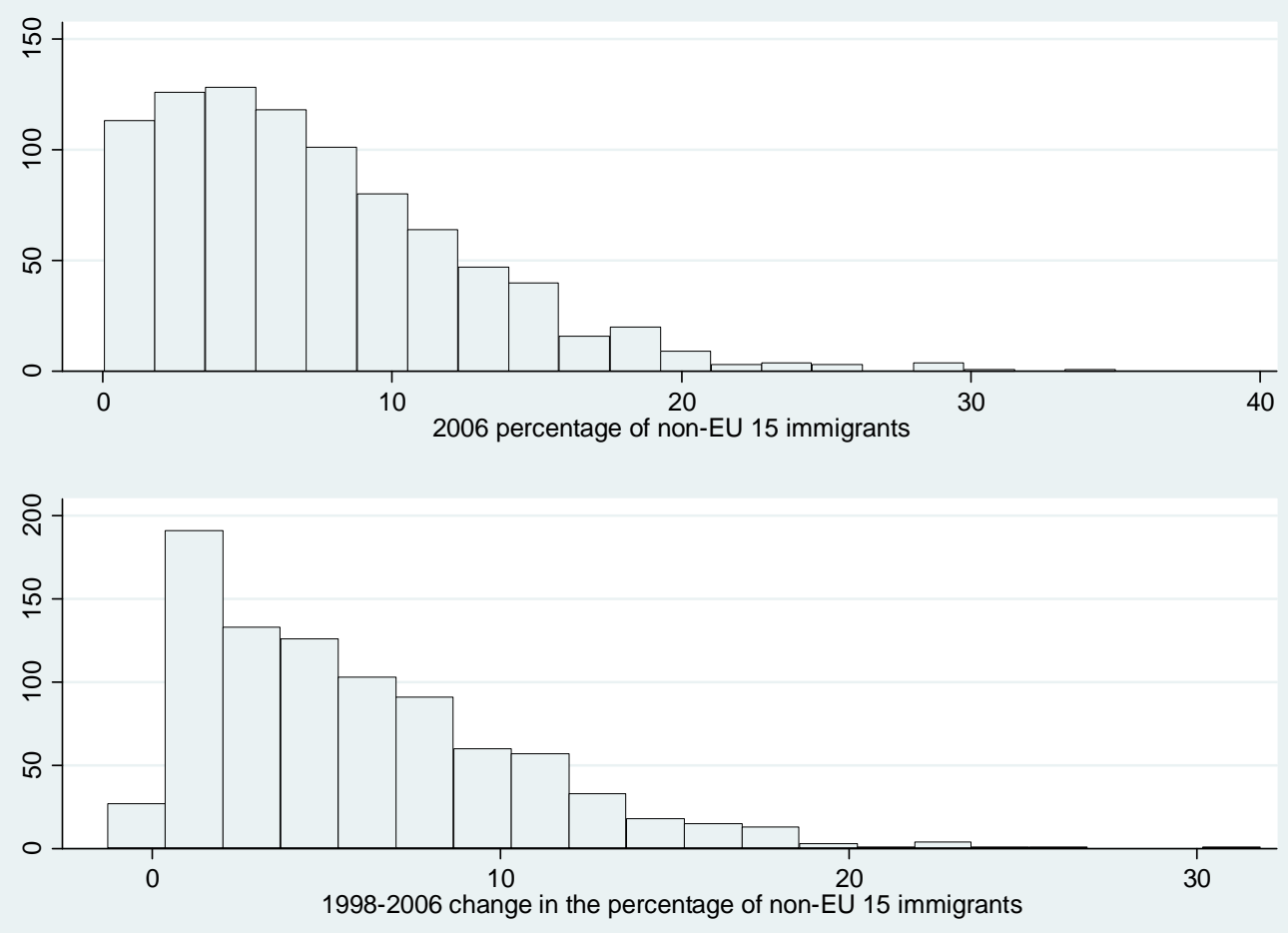

Notes: Frequency in the vertical axis. The number of observations is 878 which corresponds to the estimation sample. 


\section{Annex}

Table A1. First-stage results

\begin{tabular}{|c|c|c|c|c|c|c|}
\hline \multirow{2}{*}{ Instrument } & \multicolumn{3}{|l|}{ a)'Rentals' } & \multicolumn{3}{|c|}{ b)'Immigrants' early settlement patterns' } \\
\hline & $(1)$ & $(2)$ & $(3)$ & $(4)$ & $(5)$ & (6) \\
\hline$\Delta \overline{\text { Immigrant density }}$ & $\begin{array}{l}0.269 * * * \\
(0.030)\end{array}$ & $\begin{array}{l}0.222 * * * \\
(0.028)\end{array}$ & $\begin{array}{l}0.216^{* * *} \\
(0.026)\end{array}$ & $\begin{array}{l}0.126^{* * *} \\
(0.039)\end{array}$ & $\begin{array}{l}0.103^{* * *} \\
(0.032)\end{array}$ & $\begin{array}{l}0.109 * * * \\
(0.034)\end{array}$ \\
\hline \multicolumn{7}{|l|}{ Fiscal capacity } \\
\hline$\Delta$ Property tax base & & $\begin{array}{l}-68.040^{* * *} \\
(20.739)\end{array}$ & $\begin{array}{l}-42.147 * * \\
(17.809)\end{array}$ & & $\begin{array}{l}-90.313 * * * \\
(23.434)\end{array}$ & $\begin{array}{l}-61.895^{* * *} \\
(21.115)\end{array}$ \\
\hline$\Delta$ Debt burden & & $\begin{array}{l}-0.005 \\
(0.005)\end{array}$ & $\begin{array}{l}-0.006 \\
(0.005)\end{array}$ & & $\begin{array}{l}-0.006 \\
(0.005)\end{array}$ & $\begin{array}{l}-0.006 \\
(0.005)\end{array}$ \\
\hline $\begin{array}{l}\Delta \text { Municipality size } \\
\text { intervals }\end{array}$ & No & Yes & Yes & No & Yes & Yes \\
\hline \multicolumn{7}{|l|}{ Expenditure needs } \\
\hline$\Delta Y$ oung $(<16$ years old $)$ & & & $\begin{array}{l}-0.146 * * * \\
(0.048)\end{array}$ & & & $\begin{array}{l}-0.135^{* * *} \\
(0.050)\end{array}$ \\
\hline$\Delta$ Old $(>64$ years old $)$ & & & $\begin{array}{l}-0.868^{* * *} \\
(0.064)\end{array}$ & & & $\begin{array}{l}-0.879 * * * \\
(0.065)\end{array}$ \\
\hline$\Delta U$ Unemployment rate & & & $\begin{array}{l}0.002 \\
(0.018)\end{array}$ & & & $\begin{array}{l}0.006 \\
(0.018)\end{array}$ \\
\hline $\begin{array}{l}\text { F-test excluded } \\
\text { instruments }\end{array}$ & 80.84 & 62.04 & 69.98 & 10.15 & 10.11 & 10.12 \\
\hline Observations & 1,756 & 1,756 & 1,756 & 1,756 & 1,756 & 1,756 \\
\hline
\end{tabular}

parenthesis. ${ }^{* * *}$ denotes statistical significance at the $1 \%$ level and ${ }^{* *}$ at the $5 \%$ level. 